\title{
Selected aspects of the epidemiology of multiple sclerosis in Poland - a multicentre pilot study
}

\section{Wybrane aspekty epidemiologiczne stwardnienia rozsianego w Polsce - wieloośrodkowe badanie pilotażowe} \author{
Wiesław Drozdowskil, Zbigniew Stelmasiak \\ 'Klinika Neurologii, Uniwersytet Medyczny w Białymstoku \\ ${ }^{2}$ Katedra i Klinika Neurologii, Uniwersytet Medyczny w Lublinie \\ ${ }^{3}$ Dział Medyczny, Bayer Sp. z 0.0., Warszawa
}

Alina Kułakowska' ', Halina Bartosik-Psujek², Roman Hożejowski³ , Krystyna Mitosek-Szewczyk2,

Neurologia i Neurochirurgia Polska 2010; 44, 5: 443-452

\begin{abstract}
Background and purpose: The aim was to conduct a pilot study of selected epidemiological aspects of multiple sclerosis (MS) in Poland.

Material and methods: Cross-sectional data were collected in 21 centres providing MS treatment. The demographic profile of the patients, medical history of MS, disability status, comorbidity, and diagnostic and treatment modalities were analysed.

Results: Data on 3581 patients were obtained, including 2494 women $(69.6 \%)$ and 1030 men $(28.8 \%)$ - sex ratio $2.4: 1$. The mean age was $40.7 \pm 11.9$ years. Monofocal onset was reported in $80.8 \%$ of cases - the most frequently reported location of lesions was supratentorial (36.1\%), followed by optic nerves $(26.5 \%)$ and spinal cord $(20.1 \%)$. The mean disease duration was $10.2 \pm 8.8$ years (range 0.04-53 years), and the mean time from the first symptoms to MS diagnosis was 2.6 years. Relapsing-remitting MS was reported in 70.5\% of patients, secondary progressive in $16.8 \%$, primary progressive in $8.4 \%$, and 'benign MS' in $2.5 \%$. The mean EDSS score was $3.3 \pm 2.2$ (range 0-9.5). The family history of MS was positive in $6.4 \%$ of cases. Comorbidity mainly applied to the musculoskeletal system $(6.5 \%)$, the urinary sys-
\end{abstract}

\section{Streszczenie}

Wstęp i cel pracy: Celem badania była pilotażowa analiza wybranych aspektów epidemiologicznych stwardnienia rozsianego (SR) w Polsce.

Materiał i metody: Przekrojowe dane zebrano w 21 ośrodkach prowadzacych leczenie SR. Analizowano profil demograficzny chorych, wywiad chorobowy SR, stopień niepełnosprawności, choroby współwystępujące, metody diagnostyczne i stosowane leczenie.

Wyniki: Uzyskano dane 3581 pacjentów, w tym 2494 kobiet (69,6\%) i 1030 mężczyzn $(28,8 \%)$ - proporcja płci 2,4 : 1 . Średni wiek wynosił 40,7 $\pm 11,9$ roku. Początek jednoogniskowy odnotowano w 80,8\% przypadków - najczęściej wskazywano na nadnamiotową lokalizację uszkodzeń $(36,1 \%)$, w dalszej kolejności zajęte były nerwy wzrokowe $(26,5 \%)$ i rdzeń kręgowy (20,1\%). Choroba trwała średnio 10,2 $\pm 8,8$ roku (zakres $0,04-53$ lat), a od pierwszych objawów do ustalenia rozpoznania mijało średnio 2,6 roku. Postać nawracająco-zwalniającą SR miało 70,5\% chorych, wtórnie postępującą - $16,8 \%$, pierwotnie postępująca $-8,4 \%$, u $2,5 \%$ rozpoznano zaś „łagodne” SR. Średni stopień niesprawności w skali EDSS wyniósł 3,3 $\pm 2,2$ (zakres 0-9,5). Rodzinne występowanie SR odnotowano w 6,4\% przypadków. Wśród

Correspondence address: dr med. Alina Kułakowska, Klinika Neurologii Uniwersytetu Medycznego w Białymstoku, ul. Skłodowskiej-Curie 24A, 15-276 Białystok, e-mail: alakul@umwb.edu.pl

Received: 21.11.2009; accepted: 13.07.2010 
tem $(5.8 \%)$ and psychiatric disturbances $(5.5 \%)$. Brain magnetic resonance studies were available in $96.3 \%$ of the patients, evoked potentials in $54 \%$, and cerebrospinal fluid testing in $63.1 \%$ - of whom only $41.2 \%$ were tested for oligoclonal bands, with $84 \%$ of samples being positive. Immunomodulatory drugs were used in 842 patients $(24 \%)$, predominantly interferon beta $(81 \%)$ and glatiramer (13\%). Mitoxantrone was the most commonly used immunosuppressant.

Conclusions: This project is the first countrywide large-scale MS survey, covering approximately $18 \%$ of patients, according to our estimates. The results identify the clinical condition of the patients, as well as diagnostic and treatment modalities.

Key words: multiple sclerosis, Poland, epidemiology, diagnostics, treatment.

\section{Introduction}

Multiple sclerosis (MS), a chronic demyelinating disease, is a leading cause of neurological disability in young adults. The course of the disease and the rate of disability progression are highly unpredictable. It is estimated that roughly 1 million people worldwide suffer from MS [1], although the exact number is not known.

In Poland no epidemiological study covering a representative group of MS patients throughout the entire country has been conducted so far. In fact only a few epidemiological surveys have been carried out, and all of these have been limited to particular regions of Poland [2-5].

The purpose of this study was to collect data on the demographic profile, health status and diagnostic and therapeutic modalities of MS patients in Poland.

\section{Material and methods}

The process of cross-sectional data collection started in May 2008 and was completed in January 2009. The project involved 21 centres (university clinics, hospital wards, outpatient clinics and private surgeries) from almost the entire territory of Poland except for the following provinces: pomorskie, kujaresko-pomorskie, tódzkie and podkarpackie.

The data were collected using a specially designed form (paper questionnaire and an alternative electronic chorób współwystępujących najczęstsze były schorzenia narządu ruchu (6,5\%), układu moczowego $(5,8 \%)$ i zaburzenia psychiczne $(5,5 \%)$. Rezonans magnetyczny mózgu wykonano u $96,3 \%$ pacjentów, potencjały wywołane u $54 \%$, badanie płynu mózgowo-rdzeniowego u 63,1\% - z czego zaledwie w 41,2\% przypadków oznaczano prążki oligoklonalne (ich obecność stwierdzono w $84 \%$ próbek). Leki immunomodulujące otrzymywało 842 chorych (24\%), najczęściej były to interferon $\beta$ (81\%) i glatiramer (13\%). W immunosupresji najczęściej stosowano mitoksantron.

Wnioski: Zrealizowany projekt jest pierwszym ogólnopolskim badaniem populacji chorych na SR na tak szeroką skalę - wg naszych szacunków obejmującym ok. 18\% populacji chorych. Zgromadzone wyniki informują o stanie klinicznym chorych, najczęstszych metodach diagnostyki i leczenia.

Słowa kluczowe: stwardnienie rozsiane, Polska, epidemiologia, diagnostyka, leczenie.

form), which included queries about: demographic data, family history, concomitant diseases, first MS symptoms, disease duration, relapse activity, degree of disability on the Expanded Disability Status Scale (EDSS) [6], diagnostic methods, and immunomodulatory/immunosuppressive therapy. In addition, the study assessed the patients' quality of life using the EQ-5D scale (results of the quality of life assessment will be published separately). Doctors participating in the study were asked to take into account the data of all patients under their care in whom MS had been diagnosed based on the McDonald criteria $[7,8]$, regardless of age, disease form or disability status.

The collected data were analysed using Statistica 7.1 (StatSoft, US) and GraphPad Prism 5.0 (GraphPad Software, US).

A quality check of the data included cross-comparison of parameters gathered in the project. In case of inconsistency (e.g., the date of first symptoms was later than the date of MS diagnosis), the inconsistent data were not taken into account in the analysis.

For the collected data, descriptive statistics of their distribution were calculated, with mean/median values, quartiles, standard deviations and $95 \%$ confidence intervals.

\section{Results}

In our project, data from 3851 patients were collected, including 2494 women (69.6\%) and 1030 men (28.8\%). The female/male ratio in the study group was $2.4: 1$. 
The patients originated from 21 study sites, including academic centres (60.9\% of patients), non-academic specialty centres (31.4\%), private practice $(6.3 \%)$ and municipal healthcare units (1.4\%). The patient's setting (whether in- or outpatient) was not recorded.

Geographical location of the study sites is presented in Table 1.

The mean age of the analysed cohort was 40.7 \pm 11.9 years (range 11.2-92.3), while the mean age of women was $40.7 \pm 11.8$ years (range 11.2-92.3) and of men was $40.6 \pm 12.1$ years (range 11.8-88.2). The mean age at disease onset was $30.4 \pm 9.8$ years, and the mean duration of the disease in the study group was $10.2 \pm 8.8$ years. An average of $2.6 \pm 4.3$ years elapsed from the onset of first symptoms to MS diagnosis. Detailed patient characteristics including relapse activity are presented in Table 2 .
Table 1. Geographical distribution of the study sites and the patient cohort

\begin{tabular}{|lcc|}
\hline $\begin{array}{l}\text { Site location } \\
\text { (region) }\end{array}$ & $\begin{array}{c}\text { No. of } \\
\text { study sites }\end{array}$ & $\begin{array}{c}\text { Patients } \\
\mathbf{n}(\%)\end{array}$ \\
\hline dolnośląskie & 1 & $200(5.6 \%)$ \\
\hline lubelskie & 3 & $1016(28.4 \%)$ \\
\hline lubuskie & 1 & $90(2.5 \%)$ \\
\hline małopolskie & 1 & $107(3 \%)$ \\
\hline mazowieckie & 1 & $57(1.6 \%)$ \\
\hline opolskie & 1 & $60(1.7 \%)$ \\
\hline podlaskie & 1 & $199(5.6 \%)$ \\
\hline śląskie & 2 & $297(8.3 \%)$ \\
\hline świętokrzyskie & 2 & $165(4.6 \%)$ \\
\hline warmińsko-mazurskie & 1 & $134(3.7 \%)$ \\
\hline wielkopolskie & 4 & $703(19.6 \%)$ \\
\hline zachodniopomorskie & 3 & $553(15.4 \%)$ \\
\hline
\end{tabular}

Table 2. Patient characteristics

\begin{tabular}{|c|c|c|c|}
\hline & Females & Males & All patients* \\
\hline No. of patients & 2494 & 1030 & 3581 \\
\hline Proportion: female/male & - & - & $2.4: 1$ \\
\hline \multicolumn{4}{|l|}{ Age } \\
\hline mean (SD) & $40.7(11.8)$ & $40.6(12.1)$ & $40.7(11.9)$ \\
\hline median (range) & $40.5(11.2-92.3)$ & $39.4(11.8-88.2)$ & $40.1(11.2-92.3)$ \\
\hline \multicolumn{4}{|l|}{ Disease duration [years] } \\
\hline mean $(\mathrm{SD})$ & $10.2(8.7)$ & $10.4(9.1)$ & $10.2(8.8)$ \\
\hline median (range) & $7.8(0.08-53.1)$ & $7.5(0.04-50.8)$ & $7.6(0.04-53.1)$ \\
\hline \multicolumn{4}{|c|}{ Age at disease onset [years] } \\
\hline mean $(\mathrm{SD})$ & $30.6(10.1)$ & $30.2(9.0)$ & $30.4(9.8)$ \\
\hline median (range) & $29.5(5.08-66.4)$ & $29.0(4.76-58.5)$ & $29.3(4.8-66.4)$ \\
\hline \multicolumn{4}{|c|}{ Total number of prior relapses } \\
\hline mean (SD) & $5.73(4.29)$ & $5.38(4.39)$ & $5.62(4.31)$ \\
\hline median (range) & $4(0-28)$ & $4(0-35)$ & $4(0-35)$ \\
\hline \multicolumn{4}{|c|}{ Number of relapses in the last year (by category) } \\
\hline$\leq 1$ relapse & $1721(69.0 \%)$ & $735(71.4 \%)$ & $2496(69.7 \%)$ \\
\hline 2 relapses & $213(8.5 \%)$ & $98(9.5 \%)$ & $315(8.8 \%)$ \\
\hline 3 relapses & $39(1.6 \%)$ & $13(1.3 \%)$ & $52(1.5 \%)$ \\
\hline$\geq 4$ relapses & $11(0.4 \%)$ & $2(0.2 \%)$ & $13(0.4 \%)$ \\
\hline unknown & $510(20.4 \%)$ & $182(17.7 \%)$ & $705(19.7 \%)$ \\
\hline
\end{tabular}

*Gender was not specified in 57 cases

$S D-$ standard deviation 


\begin{tabular}{|lcc|}
\hline First symptoms & No. of pts. & \% \\
\hline supratentorial & 1046 & 36.1 \\
\hline optic nerves & 766 & 26.5 \\
\hline spinal cord & 581 & 20.1 \\
\hline brain stem & 242 & 8.4 \\
\hline cerebellum & 223 & 7.7 \\
\hline other & 38 & 1.3 \\
\hline
\end{tabular}

Fig. 1. First symptoms location - percentage distribution

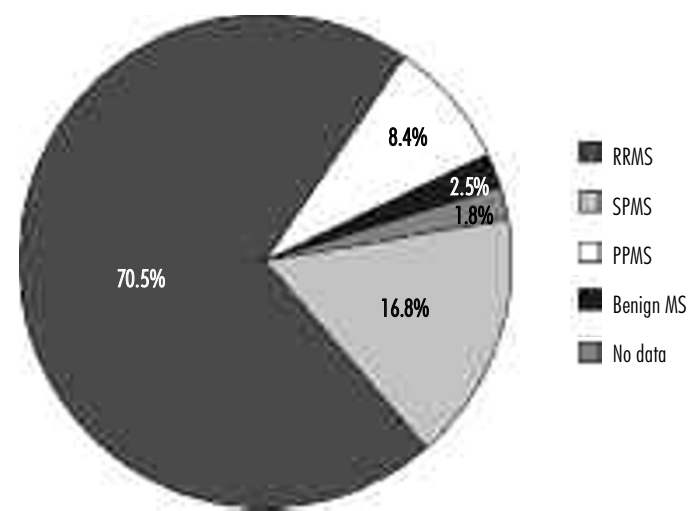

SPMS - secondary progressive multiple sclerosis, RRMS - relapsing-remitting multiple sclerosis, PPMS - primary progressive multiple sclerosis

Fig. 2. Multiple sclerosis types in the study group - percentage distribution

The disease onset in the majority of patients was monofocal $(2896 / 3581,80.8 \%)$. The most common locations of the first symptoms are presented in Fig. 1.

Multifocal onset occurred in 561/3581 patients (15.7\%), as follows: two symptoms in 506 patients (14.1\%), three symptoms in 52 patients (1.5\%), four symptoms in 3 patients $(0.08 \%)$. No data on the location of the first symptoms were available from 124 patients (3.5\%).

A majority of the study group $(2523 / 3581,70.5 \%)$ had relapsing-remitting multiple sclerosis (RRMS). Detailed data on the occurrence of specific forms of the disease are shown in Fig. 2.

In this study 'benign MS' has been singled out; it is defined as the occurrence of relapses with complete remission, or very minor impairment and disability not exceeding an EDSS score of 3 after 10 years from the disease onset. This form of MS was presented by only $2.5 \%$ of the patients.

The degree of disability as evaluated by the EDSS score was $3.34 \pm 2.20$ (range $0-9.5)$ - see Table 3 . The histogram of the percentage distribution of the vari-

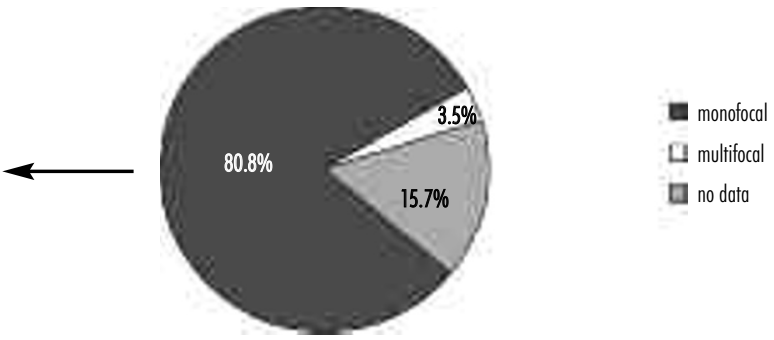

able and the categorised distribution by intervals are presented in Fig. 3 and Table 3, respectively.

Patients with mobility restricted to an extent that at least required the use of a cane (EDSS $\geq 6$ ) accounted for $19.7 \%$ of the study group. Patients who were unable to walk without aid and required a wheelchair constituted $5 \%$ of the sample. The analysis showed a statistically significant correlation between disease duration and degree of disability, both in patients with relapsing-remitting $\left(r^{2}=0.3095, p<0.0001\right)$ and in those with primary progressive $\left(r^{2}=0.1737, p<0.0001\right)$ MS - see Fig. 4 .

Family history data for MS were recorded in 2871 patients, of whom a negative history was found in 2687 (93.6\%), and a positive history in 184 patients (6.4\%). No history information was available in 710 (19.8\%) patients. Out of the 184 cases in which the family history was positive, 7 patients had more than one family member with the disease; for details see Table 4 .

The study also collected data on the occurrence of other disease burdens besides MS. Disease burdens were grouped according to the MedDRA SOC international classification. The absence of any burdens (other than the underlying disease) was reported in 2405 (67.2\%) patients. The remaining patients $(32.8 \%)$ had a history indicative of dysfunction primarily in the following organ systems: musculoskeletal system, urinary system, mental disorders and other central nervous system disorders. These dysfunctions occurred with an incidence of $>5 \%$ in the study group. Detailed data on comorbidity in the study group are shown in Fig. 5.

The frequency of use of the following examinations was also assessed: magnetic resonance imaging (MRI) of the brain, evoked potentials and cerebrospinal fluid testing, including determination of the presence of oligoclonal bands (Fig. 6).

In the study group, diagnosis of MS was made exclusively on the basis of the clinical picture in only 11 patients $(0.3 \%)$. 
Table 3. Disability assessment (EDSS score) in the studied cohort

\begin{tabular}{|lccc|}
\hline & Females & Males & All patients* \\
\hline No. of available scores & 2494 & 1030 & 3581 \\
\hline EDSS score & & & \\
\hline mean (SD) & $3.31(2.16)$ & $3.47(2.28)$ & $3.34(2.20)$ \\
\hline median (range) & $3(0-9.5)$ & $3(0-9.5)$ & $3(0-9.5)$ \\
\hline EDSS score by category & & & \\
\hline$\leq 1.5$ & $696(27.9 \%)$ & $294(28.5 \%)$ & $1012(28.3 \%)$ \\
\hline $\begin{array}{l}2.0-2.5 \\
3.0-3.5\end{array}$ & $484(19.4 \%)$ & $158(15.3 \%)$ & $648(18.1 \%)$ \\
\hline$\geq 4.0$ & $355(14.2 \%)$ & $144(14.0 \%)$ & $506(14.1 \%)$ \\
\hline unknown & $904(36.2 \%)$ & $410(39.8 \%)$ & $1331(37.2 \%)$ \\
\hline
\end{tabular}

*gender was not specified in 57 cases

EDSS - Expanded Disability Status Scale; SD - standard deviation

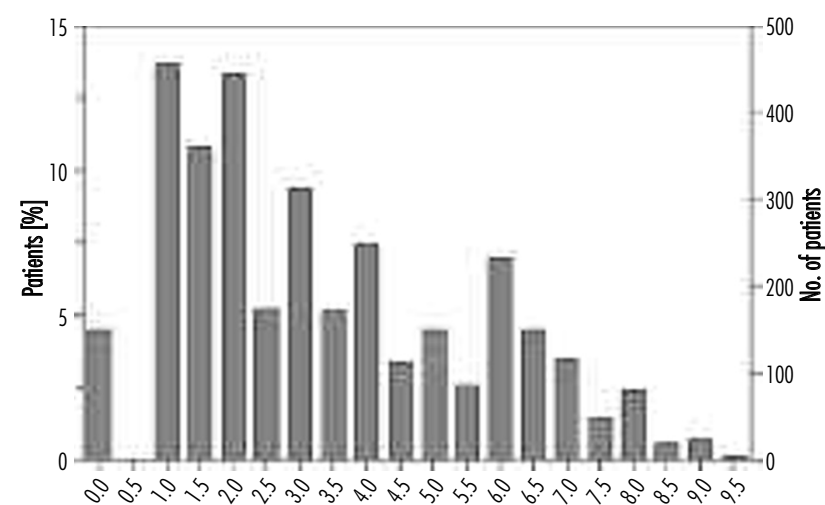

EDSS

Fig. 3. Disability score (EDSS) in the studied cohort - percentage distribution

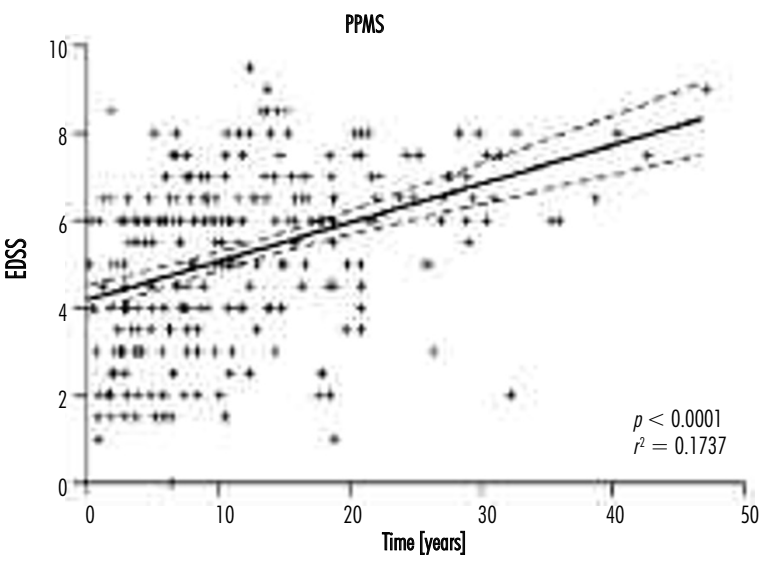

Dashed lines demarcate $95 \% \mathrm{Cl}$ of the linear regression line

Fig. 4. Correlation between disease duration and EDSS score in primary progressive (PPMS) and relapsing-remitting multiple sclerosis (RRMS)
Table 4. Details of familial occurrence of MS - percentage distribution of involved family members

\begin{tabular}{|lcc|}
\hline Involved family member & $\mathbf{n}$ & $\mathbf{\%}$ \\
\hline Member of extended family & 85 & 50.0 \\
\hline Sister & 28 & 16.5 \\
\hline Mother & 19 & 11.2 \\
\hline Father & 17 & 10.0 \\
\hline Brother & 14 & 8.2 \\
\hline Mother + member of extended family & 2 & 1.2 \\
\hline Father + member of extended family & 2 & 1.2 \\
\hline Sister + member of extended family & 1 & 0.6 \\
\hline Brother + member of extended family & 1 & 0.6 \\
\hline Brother + mother & 1 & 0.6 \\
\hline
\end{tabular}

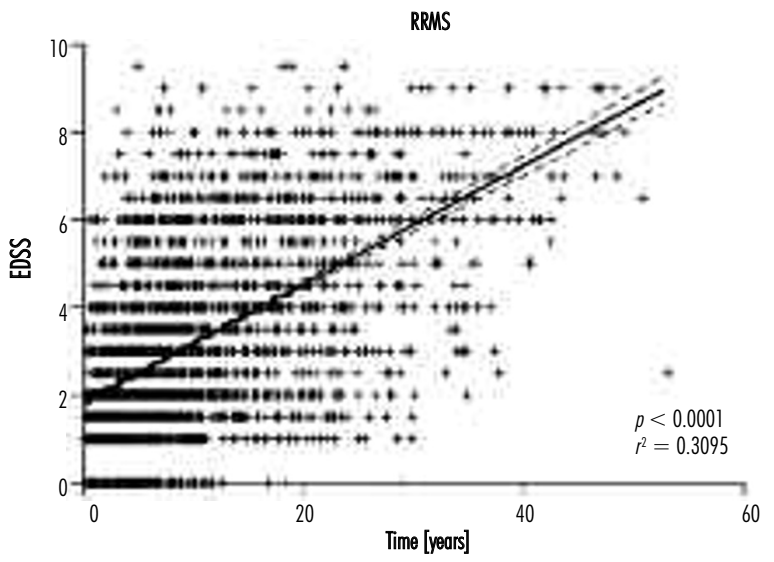




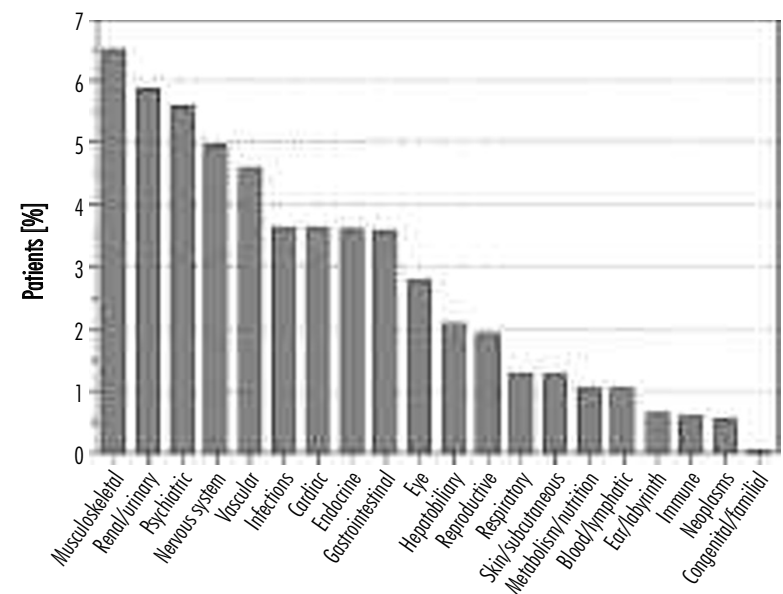

Fig. 5. Comorbidity in the study group

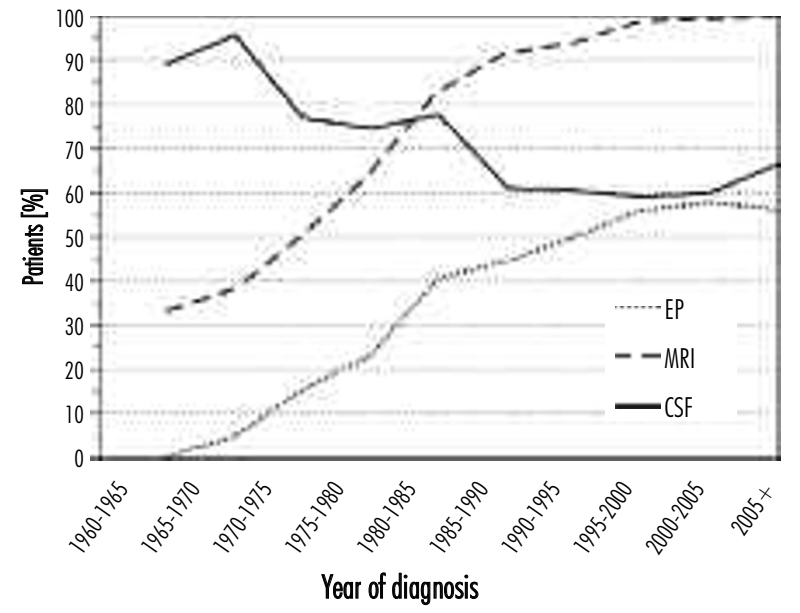

EP - evoked potentials, MRI - magnetic resonance imaging, CSF - cerebrospinal fluid Note: individual diagnostic tests might not necessarily be performed at the time of primary diagnosis of MS

Fig. 6. Percentage of patients in whom the below diagnostic tests were used vs. the year of diagnosis

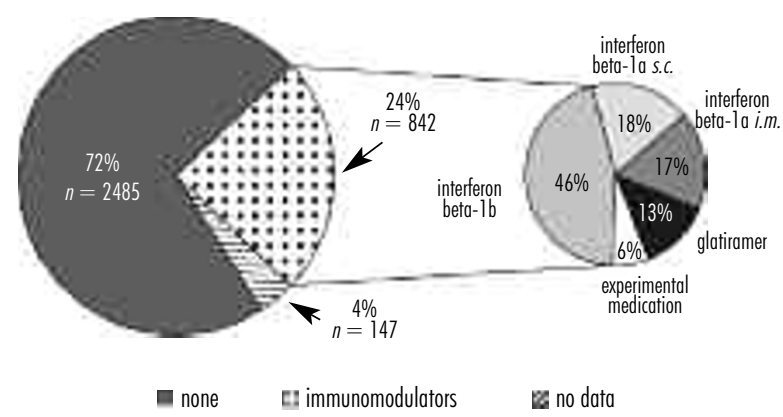

Fig. 7. Patients under immunomodulatory treatment (excluding steroids) percentage distribution
MRI was performed in 3446 patients (96.2\%). Information regarding the use of contrast enhancement was achieved for 2509 patients. Out of this group, imaging was carried out using contrast enhancement in 73.7\% (1850 patients). Lesions in T2-weighted images typical of MS were found in 3208 cases $(89.6 \%)$, in 43 cases $(1.2 \%)$ changes were atypical for MS, while in 19 patients $(0.5 \%)$ images were normal. No data were available for 311 patients $(8.7 \%)$. In the event of focal lesions, radiological descriptions did not state their exact number in $85.4 \%$ of cases (2943 patients).

Testing of the cerebrospinal fluid was documented in 2258 patients (63.1\%). Out of this group, the test for the presence of oligoclonal bands was performed in only $930(41.2 \%)$ patients. In patients who had their cerebrospinal fluid tested for oligoclonal bands, these were found in 785/930 (84\%) patients.

Evoked potentials were recorded in 1933 patients (54\%); this test was not performed in 1645 patients (45.9\%) and in 3 cases $(0.08 \%)$ no information was provided on whether such a test had been performed.

The questionnaires also reported whether the patients were treated with immunomodulating or immunosuppressive drugs (with the exception of steroids).

The number of patients receiving immunomodulatory drugs at the time of the study was 842 (24\%), while 94 patients (3\%) were receiving immunosuppressive drugs. Mitoxantrone (81\%) and azathioprine (18\%) were among the most widely used immunosuppressive agents.

The percentage distribution of different immunomodulatory drugs is presented in Fig. 7 (immunoglobulin $G$ is omitted because it was taken by one patient only). The category of 'experimental drugs' includes all pharmaceutical products taken within a clinical trial setting, including double-blinded placebo-controlled studies.

Table 5 shows a summary of all immunomodulatory and immunosuppressive agents that have ever been taken by the patients $(n=1836)$ in the study group. It should be noted that the chart takes into account the fact that a patient could take more than one drug.

\section{Discussion}

During the study, data on 3851 patients were collected. Given the prevalence of multiple sclerosis of $55-57 / 100000$ found in the epidemiological studies con- 
ducted in the north-western [4] and in the eastern parts of Poland [5], it seems that the examined group represents roughly $18 \%$ of the entire population of Polish MS patients.

In the study group, a significant female predominance was evident (female to male ratio of $2.4: 1$ ) that was comparable to previously reported observations [9-13]. Some recent publications show that the female predominance in MS patients seems to be gradually increasing [14]. Also other demographic data, i.e., age at disease onset and disease duration, do not differ significantly from those ascertained in the course of epidemiological studies conducted in various regions of Poland $[4,5]$, as well as in a neighbouring country Germany [11].

In most patients, the disease onset was monofocal, with symptoms indicative mainly of supratentorial location of lesions. The data are consistent with the reports of other authors who observed a monofocal onset of MS in more than $80 \%$ of patients [15].

Compared to other observations $[5,11,16]$, we found a shorter time lag between the occurrence of the first symptoms and diagnosis, which in our study was 2.6 years on average. It seems that the introduction of the McDonald diagnostic criteria and better access to MRI contribute to the improvement of the diagnosis [17].

In the study group, most patients reported a relapsing-remitting form of the disease $(70.5 \%)$, with relapse activity within the last 12 months ranging from 0 to 6 relapses - a mean of 0.7 relapses per patient. A relatively small fraction of patients had the secondary progressive $(16.8 \%)$, primary progressive (8.4\%) and benign (2.5\%) course of the disease. Compared to data from the literature on the natural course of MS $[9,18]$, we noted in our group an over-representation of the relapsing-remitting form of MS and consequently under-representation of other forms. This is probably due to the fact that the study primarily included centres involved in immunomodulatory therapy and it is this group of patients (who return regularly for medication) that neurologists have the easiest access to.

The patients' degree of disability was assessed on the EDSS scale. The mean score was 3.3. Having taken into account the mean duration of the disease (10.2 years), the mean degree of disability that we recorded is very close to the German observation, which is similar in terms of methodology (mean EDSS $=3.5$, mean disease duration 12.7 years) [11]. In the subgroup with higher levels of disability (EDSS $\geq 4$ ) a larger proportion of men (39.8\%) compared to women (36.2\%) was
Table 5. Immunomodulatory/immunosuppressive agents that have ever been taken in the studied cohort (steroids not included)

\begin{tabular}{|lcc|}
\hline $\begin{array}{l}\text { Immunomodulator } \\
\text { /immunosuppressant }\end{array}$ & No. of patients & \% of cases \\
\hline Interferon beta-1b & 728 & 43.2 \\
\hline Interferon beta-1a (S.C.) & 251 & 14.9 \\
\hline Interferon beta-1a (I.M.) & 206 & 12.2 \\
\hline Glatiramer acetate & 199 & 11.8 \\
\hline Investigational drug & 180 & 10.7 \\
\hline Mitoxantrone & 170 & 10.1 \\
\hline Azathioprine & 74 & 4.4 \\
\hline Immunoglobulin G & 19 & 1.1 \\
\hline Cyclophosphamide & 9 & 0.5 \\
\hline TOTAL & 1836 & $109.0 *$ \\
\hline
\end{tabular}

S. C. - subcutaneous, I.M. - intramuscular

* Percentages of cases do not add up to 100 because some patients were administered more than one drug

found, which is in agreement with previous reports indicating more severe disease course in males [19].

Data collected on concomitant diseases indicate that most patients $(67.2 \%)$ did not have any burdens beyond the underlying disease. Most frequently (in more than $5 \%$ of patients) reported concomitant diseases belonged to the following three categories: 1) muscular and connective tissue, bones; 2) kidneys and the urinary system; 3) mental disorders. Because in the questionnaire, neurologists only reported the categories of concomitant diseases (without specifying the diagnosis), from a practical point of view it is difficult to resist the impression that the problems mentioned may be causally related to the underlying disease, e.g., the presence of paresis and spasticity predisposes to spinal pain syndrome, micturition disturbances are associated with urinary tract infections, and disorders of mood and cognitive functions are very common in patients with MS. However, cancer or cardiovascular diseases frequently occurring in the general population were very rarely recorded in the study group of patients.

Data on the prevalence of MS in the patient's family were available for 2871 patients - in 184 cases disease in their relatives was reported. Out of these individuals, 5 patients reported more than one case of MS in the family (excluding the proband). In such cases a first-degree relative was always one of the affected family members and siblings were most often involved rather than parents. Our data are similar to other pre- 
vious observations in terms of the family pattern of the disease occurrence $[15,20]$.

Data collected on diagnostic methods show that MRI (not always contrast-enhanced) is currently the most widely used supporting test in the diagnosis of MS, and its use has significantly increased in recent years. MRI was performed in $96.2 \%$ of patients. Unfortunately, we found that in $85.4 \%$ of the cases radiological descriptions did not specify the exact number of lesions. The lack of precise MRI descriptions undoubtedly renders radiological diagnostic criteria difficult to implement in routine practice $[21,22]$.

Cerebrospinal fluid was examined in $63.1 \%$ of patients. The use of this test has decreased in recent years, which may be due to easier access to non-invasive diagnostic methods. In patients who had their cerebrospinal fluid tested, the presence of oligoclonal bands, which are indicative of intrathecal synthesis of immunoglobulins [23,24], was assessed in only $41.2 \%$ of the patients. In approximately $8 \%$ of patients there was no information in this regard. This information suggests that intrathecal synthesis of immunoglobulins, which should be evaluated in each patient with suspected MS in whom cerebrospinal fluid is collected for testing, is evaluated too infrequently. The relatively low frequency of oligoclonal band testing is probably due to methodological difficulties, deficiency of proper equipment and lack of experienced diagnosticians.

In more than half of the patients, tests of evoked potentials were performed, yet our survey did not specify their type. In the context of widespread use of MRI, the large inter-subject variability of evoked potentials $[25,26]$, and the introduction of the McDonald diagnostic criteria, which take into account visual evoked potentials only in the diagnosis of primary progressive MS [7], it may be somewhat surprising that the frequency of electrophysiological tests has not decreased. Perhaps this is due to their non-invasive nature, wide availability and relatively low cost.

At the time of data collection, immunomodulatory drugs were being given to 842 respondents $(24 \%)$ these were mainly beta-interferons ( $81 \%)$, but $6 \%$ of the patients also participated in clinical trials of various drugs. The observed treatment rate $(24 \%)$ is considerably higher than the estimates provided by the patient advocacy groups (about $5 \%$ ). This may stem from the fact that the study mainly involved centres engaged in immunomodulatory treatment, and it does not change the fact that immunomodulatory drugs are used in Poland much less frequently than in Western European countries, e.g., in Germany about 50\% of patients receive such treatment [11]. Immunosuppressive agents were used in 94 patients (3\%), which is in turn much less than, for example, in Germany (approximately 16\%) [11]. Like in Poland's western neighbours, mitoxantrone and azathioprine were the most frequently administered drugs. The study did not examine the use of steroids.

This was a cross-sectional study, and it primarily involved centres engaged in immunomodulatory therapy. Judgement regarding the level of access to immunomodulatory treatment in particular regions of the country is difficult, since not all of the MS centres which provide immunomodulatory treatment participated in this study.

Data that may shed some light on this matter can however be obtained from independent research companies monitoring the pharmaceutical market in Poland (e.g. IMS Health Poland). These reports show that the number of MS patients receiving disease-modifying treatment varies widely between regions, with the highest numbers of treated patients in wielkopolskie and matopolskie regions and the lowest in lubuskie, warminskomazurskie and opolskie (IMS Health data Q3/2009; used with permission of IMS Health Poland).

Estimates regarding the percentage of MS patients with immunomodulatory therapy remain dubious, as the exact prevalence of the disease in Poland is unknown. If, however, absolute numbers of treated patients are compared to the population of the regions, still wielkopolskie and matopolskie provinces have the highest proportions of treated patients, while ślaskie and warminskomazurskie have the lowest - although the former region has a relatively high absolute number of treated patients (more than 200). There is more than a threefold difference between the region with the highest and the one with the lowest proportion of treated patients.

The large variation of the study centres should be noted - the study looked at patients treated in university clinics, hospital wards, outpatient clinics and private surgeries, located both in large urban areas and in small towns. The obtained database thus allows us to assess diverse patient populations. Although in some cases the precision of data collection (lack of responses to certain questions) has raised concerns, this project is the first epidemiological study of multiple sclerosis in Poland carried out on such a large scale, providing an insight into the health situation of the Polish population of patients. 


\section{Conclusions}

1. We estimate that this first countrywide survey in MS patients covered approximately $18 \%$ of the Polish population of these patients.

2. The demographic characteristics of patients studied are similar to those obtained during population-based epidemiological studies conducted in several Polish regions, which seems to indicate that the data collected are representative of the Polish population of MS patients.

3. Only the fact that the study primarily involved centres engaged in immunomodulatory therapy may slightly distort some of the results, e.g., by overestimating the proportion of patients treated with diseasemodifying drugs.

4. Like in other countries, it is strongly advisable to establish a nation-wide MS registry that would allow the precise determination of the prevalence and incidence of multiple sclerosis in Poland, as well as to help determine the necessity for healthcare.

\section{Acknowledgements}

This survey was a joint initiative of the Polish Society of Multiple Sclerosis and Bayer Sp. z o.o., Warszawa, Poland. Financial support was provided by Bayer Sp. z o.o., Warszawa, Poland.

The authors wish to thank the following investigators who collected data for this report:

Białystok: Dr. H. Borowik, Dr. K. Kapica-Topczewska; Cibórz: Dr. G. Adamcewicz; Katowice: Dr. M. Huć; Kielce: Dr. I. Durek-Widz; Konin: Dr. H. Krupczyńska; Kraków: Dr. S. Rusek; Lublin: Dr. E. Belniak, Dr. M. Kulka, Dr. M. Mazurkiewicz-Kanar, Dr. E. Porębska-Piwowarek; Olsztyn: Dr. E. Kędzierska; Opole: Dr. M. Gardzińska; Poznań: Dr. H. Hertmanowska, Dr. D. Kleczewska-Ratajczak, Dr. M. Moskalik, Dr. E. Tokarz-Kupczyk, Dr. J. Wencel, Dr. H. Wyglądalska-Jernas; Sandomierz: Dr. G. Wolak; Szczecin: Dr. T. Korwin-Piotrowska, Dr. R. Jałowiński, Dr. D. Nocoń, Prof. A. Potemkowski, Dr. G. Szecherew; Warszawa: Dr. L. Darda Ledzion; Włodawa: Dr. E. PorębskaPiwowarek; Wrocław: Dr. E. Gruszka, Dr. A. Pokryszko-Dragan; Zabrze: Dr. K. Kubicka.

\section{Disclosure}

Roman Hożejowski is a full-time employee of Bayer Sp. z o.o., Warsaw, Poland. Alina Kułakowska,
Halina Bartosik-Psujek, Krystyna Mitosek-Szewczyk, Wiesław Drozdowski, Zbigniew Stelmasiak report no conflict of interest.

\section{References}

1. Compston A., Coles A. Multiple sclerosis. Lancet 2002; 359: 1221-1231.

2. Cendrowski W., Wender M., Dominik W., et al. Epidemiological study of multiple sclerosis in western Poland. Eur Neurol 1969; 2: 90-108.

3. Wender M., Kowal P., Pruchnik-Grabowska D., et al. Stwardnienie rozsiane - rozpowszechnienie i zapadalność wśród ludności miejscowej w zachodniej Polsce. Neurol Neurochir Pol 1987; 21: 33-39.

4. Potemkowski A. Analiza epidemiologiczna stwardnienia rozsianego w województwie szczecińskim: ocena zachorowalności i chorobowości w latach 1993-1995. Neurol Neurochir Pol 1999; 33: 34-44.

5. Łobińska A., Stelmasiak Z. Wybrane epidemiologiczne aspekty stwardnienia rozsianego w populacji miasta Lublina. Neurol Neurochir Pol 2004; 38: 361-366.

6. Kurtzke J.F. Rating neurological impairment in multiple sclerosis: an expanded disability status scale (EDSS). Neurology 1983; 33: 1444-1452.

7. McDonald W.I., Compston A., Edan G., et al. Recommended diagnostic criteria for multiple sclerosis: guidelines from the International Panel on the diagnosis of multiple sclerosis. Ann Neurol 2001; 50: 121-127.

8. Polman C.H., Reingold S.C., Edan G., et al. Diagnostic criteria for MS: 2005 revision to the "McDonald Criteria". Ann Neurol 2005; 58: 840-846.

9. Weinshenker B.G., Bass B., Rice G.P., et al. The natural history of multiple sclerosis: a geographically based study. I. Clinical course and disability. Brain 1989; 112: 133-146.

10. Rodriguez M., Siva A., Ward J., et al. Impairment, disability, and handicap in multiple sclerosis: a population-based study in Olmsted County, Minnesota. Neurology 1994; 44: 28-33.

11. Flachenecker P., Stuke K., Elias W., et al. Multiple Sclerosis Registry in Germany. Dtsch Arztebl Int 2008; 105: 113-119.

12. Koch-Henriksen N. The Danish Multiple Sclerosis Registry: a 50-year follow-up. Mult Scler 1999; 5: 293-296.

13. Pittock S.J., Mayr W.T., McClelland R.L., et al. Disability profile of MS did not change over 10 years in a population-based prevalence cohort. Neurology 2004; 62: 601-606.

14. Orton S.M., Herrera B.M., Yee I.M., et al. Sex ratio of multiple sclerosis in Canada: a longitudinal study. Lancet Neurol 2006; 5: 932-936.

15. Eriksson M., Andersen O., Runmarker B. Long-term followup of patients with clinically isolated syndromes, relapsing remitting and secondary progressive multiple sclerosis. Mult Scler 2003; 9: 260-274.

16. Goodin D.S. Survey of multiple sclerosis in Northern California. Northern California MS Study Group. Mult Scler 1999; 5: 78-88.

17. Marrie R.A., Cutter G., Tyry T., et al. Changes in the ascertainment of multiple sclerosis. Neurology 2005; 65: 1066-1070. 
18. Confavreux C., Vukusic S. Natural history of multiple sclerosis: a unifying concept. Brain 2006; 129: 606-616.

19. Tremlett H., Paty D., Devonshire V. Disability progression in multiple sclerosis is slower than previously reported. Neurology 2006; 66: 172-177.

20. Sadovnick A.D., Yee I.M., Ebers G.C., et al. Effect of age at onset and parental disease status on sibling risk for MS. Neurology 1998; 50: 719-723.

21. Barkhof F., Rocca M., Francis G., et al.; Early Treatment of Multiple Sclerosis Study Group. Validation of diagnostic magnetic resonance imaging criteria for multiple sclerosis and response to interferon beta-1a. Ann Neurol 2003; 53: 718-724.

22. Tintoré M., Rovira A., Río J., et al. New diagnostic criteria for multiple sclerosis. Application in first demyelinating episode. Neurology 2003; 60: 27-30.

23. Thompson E.J., Freedman M. Cerebrospinal fluid analysis in the diagnosis of multiple sclerosis. Adv Neurol 2006; 98: 147-160.

24. Antel J., Bar-Or A. Roles of immunoglobulins and B cells in multiple sclerosis: from pathogenesis to treatment. $J$ Neuroimmunol 2006; 180: 3-8.

25. Halliday A.M., McDonald W.I., Mushin J. Delayed visual evoked response in optic neuritis. Lancet 1972; 1: 982-985.

26. Lee K.H., Hashimoto S.A., Hooqe J.P., et al. Magnetic resonance imaging of the head in the diagnosis of multiple sclerosis: a prospective 2-year follow-up with comparison of clinical evaluation, evoked potentials, oligoclonal banding, and CT. Neurology 1991; 41: 657-660. 